Mgr Jekatierina Mielniczuk

Uniwersytet Marii Curie-Skłodowskiej

e-mail: katiamielniczuk@gmail.com

\title{
Категория рыцарства и символика рыцаря в сверхповести Елены Гуро Бедный рыцарь (в контекстуальном освещении) ${ }^{1}$
}

\begin{abstract}
Всякий раз наставала эпоха идейного и поэтического двоевластия, и шла работа усвоений; восприятие классических сюжетов иное в Roman de Troie, чем, например, у Боккаччо и французских псевдоклассиков. Уследить процессы этих усвоений, их технику, разобраться в встречных течениях, сливавшихся в разной мере для новых созданий, представляется интересной задачей анализа».

А.Н. Веселовский (Веселовский 1989, 304)
\end{abstract}

Материалом исследования в настоящей статье является сверхповесть Елены Гуро Бедный рыцарь (1913 год), рассматриваемая в контексте философско-эстетических исканий в России рубежа XIX-XX веков. Это повесть метафизического состояния сознания. Духовная ценность данного произведения заключается в том, что оно указывает метаморфозу души матери главного героя - Эльзы. Бедный рыцарь изображает метафизический путь героини к просветлению и преображению, а также открывает перед читателем процесс сакрального посвящения, по ходу которого сын - Рыцарь - посвящает свою мать в любовь и в ее тайну. В повести Гуро понятие «рыцарь» сохраняет свое архетипическое значение и отсылает к определенной культурной традиции (Цимборска-Лебода 1999, 189).

1 Публикация статьи осуществляется при поддержке Университета Марии Кюри-Склодовской в Люблине в рамках гранта гуманитарного факультета. 
В известных нам литературоведческих работах творчество Гуро до сих пор рассматривалось в различных аспектах: художественного метода писательницы и принадлежности ее наследия к тому или иному направлению в искусстве XX века (Н.И. Харджиев, Е. Ковтун, В.Ф. Марков, В. Усенко, Г. Айги, В.А. Сарычев); выявления некоторых особенностей поэтики ее произведений (Бедный pыщарь, Шарманка и др.), наличия в них связей с теософской, антропософской, апокрифической, религиозной и мифологической традициями (3. Эндер, B.Н. Топоров, 3. Минц, Н. Башмакова, М. Цимборска-Лебода, Н. Гурьянова, Е. Тырышкина). Целью настоящей работы является контекстуальный анализ и герменевтическая интерпретация сверхповести; при этом учитывается специфика восприятия самим автором феномена рыцарства. Новизна предпринятого нами исследования заключается в том, что впервые предлагается интепретация вышеуказанной сверхповести в контексте рыцарской традиции, рыцарского мифа о Парсифале и Лоэнгрине, который несомненно присутствовал в русском культурном дискурсе рубежа XIX-XX веков.

Предпосылкой и своеобразной отправной точкой в процессе исследования данной проблематики послужила следующая мысль русского историка литературы, создателя теории втсречных течений, Александра Веселовского:

Объясняя сходство мифов, сказок, эпических сюжетов у разных народов, исследователи расходятся обыкновенно по двум противоположным направлениям: сходство либо объясняется из общих основ, к которым предположительно возводятся сходные сказания, либо гипотезой, что одно из них заимствовало свое содержание из другого. В сущности, ни одна из этих теорий в отдельности не приложима, да они и мыслимы лишь совместно, ибо заимствование предполагает в воспринимающем не пустое место, а встречные течения, сходное направление мышления, аналогические образы фантазии. Теория "заимствования" вызывает, таким образом, теорию "основ", и обратно... (Веселовский 1889, 115-116).

В своих рассуждениях ученый подчеркивает важность не самих заимствований в литературе, а их трансформации, возможной переработки, адаптации в национальной литературной традиции, а также своего рода приспособления к творческой индивидуальности писателя. Данная закономерность проявилась в русской культуре рубежа XIX-XX веков, открывшейся в это время западным инспирациям, перенимавшей мировой духовный тезаурус. «Серебряный век русской литературы представляет собой время изменения образов и тем, символов и идей, духовно-нравственных и нравственно-эстетических ценностей. Художники и поэты, [...] стремятся создать новое слово и нового человека эпохи», - замечает литературовед Александра Матрусова (Матрусова 2011, 3). Особой же заинтересованностью в то время пользовались рыцарские образы, 
заимствованные из старогерманских легенд и сказок (легенд Артуровского цикла (Матрусова 2011, 3)), а также из куртуазной литературы (культ Дамы сердца). По мнению современного американиста-литературоведа Юрия Серенкова, рыцарские мотивы были «интегрирующим смысловым элементом» (Серенков 2009, 2) художественного миросозерцания всей Европы.

Проникновению рыцарской тематики в русскую культуру уже в эпоху золотого века способствовали, прежде всего, многочислинные переводы произведений западных писателей и поэтов: Джорджа Гордона Байрона, Иоганна Гете, Фридриха Шиллера, Вальтера Скотта (Гиленсон 2016). Романтические рыцарские образы создают в своих сочинениях Александр Пушкин (Жил на свете рыцарь бедный..., Сиены из рыцуарских времен, 1835 год), Михаил Лермонтов (Молитва (Я, Матерь Божия), 1837 год). Лирический герой их произведений - это доблестный, самоотверженный рыцарь, готовый нести страстную службу своему идеалу².

Необходимо также отметить, что особой притягательностью пользовался в России роман Мигеля Сервантеса Дон Кихот. Главный герой произведения послужил импульсом к созданию новых сюжетов многим российским творцам художественного слова, а по мнению Виссариона Белинского: «Дон Кихотом началась новая эра искусства, нашего, новейшего искусства» (Белинский 1982, 305). Рыцарь Печального Образа был вдохновлением для Николая Гоголя (Мертвые души) ${ }^{3}$, Ивана Тургенева (Гамлет и Дон Kuхот) (Тургенев 1860), Николая Лескова (Очарованный странник) [Лесков 2008] ${ }^{4}$, Антона Че-

2 По мнению А.Н. Матрусовой: «Многочисленные рыцарские образы - заметное явление в русской литературе XIX века. [...] Однако у Жуковского лишь однажды встречается сильно видоизменненный Артуровский сюжет - баллада "Рыцарь Адельстан", а "бедный рыцарь" Пушкина не схож с рыцарями Круглого стола, которые увлечены поиском ускользающего, недостижимого, невозможного, а именно - Грааля» (Матрусова 2011, 3).

3 Н.В. Гоголь в своих воспоминаниях о А.С. Пушкине писал следующие: «Он уже давно склонял меня приняться за большое сочинение, и наконец, один раз, после того как я ему прочел одно небольшое изображение небольшой сцены, но которое, однако ж, поразило его больше всего мной прежде читанного, он мне сказал: “Как с этой способностью угадывать человека и несколькими чертами выставлять его вдруг всего, как живого, с этой способностью не приняться за большое сочинение! Это просто грех!” Вслед за этим начал он представлять мне слабое мое сложение, мои недуги, которые могут прекратить мою жизнь рано; привел в пример Сервантеса, который хотя и написал несколько очень замечательных и хороших повестей, но, если бы не принялся за “Донкишота”, никогда бы не занял того места, которое занимает теперь между писателями, и в заключенье всего отдал мне свой собственный сюжет, из которого он хотел сделать сам что-то вроде поэмы и которого, по словам его, он бы не отдал другому никому. Это был сюжет Mepmвых душ»» (Гиппиус 2014, 114).

4 См.: «Форма рассказа о приключениях в Очарованном страннике действительно напоминает и разъезды Чичикова по окрестным помещикам, и выезды Дон Кихота в по- 
хова (На пути) (Чехов 1984)5, Федора Достоевского (Идиот) (Достоевский 1989) ${ }^{6}$, Дмитрия Мережковского (Вечные спутники) (Мережковский 1995), позже Михаила Булгакова (Мастер и Маргарита), Андрея Платонова (Чевенгур) и мн. др. «Именно в России (и в этом смысле только Англия может составить ей конкуренцию) Дон Кихот нашел своих наиболее горячих почитателей, наиболее глубоких истолкователей, наиболее пришелся "ко двору"» (Багно 2009, 193) ${ }^{7}$, - утверждает литературовед-испанист Всеволод Багно.

В этой связи, существенно учесть также факт появления в русской культуре инспирирующей мысли Рихарда Вагнера, чему способствовала волна успешных гастролей в 1863 году в Петербурге ${ }^{8}$. Как известно, автор Лоэнгрина создает образ рыцаря-лебедя, который прибыл с миссией спасти даму своего сердца. Происхождение героя овеянно тайной, а имя его остается загадкой даже для самой избранницы9. Позже вагнеровские мотивы найдут свое отражение в поэзии Александра Блока и Андрея Белого (Жирмунский 1977; Жеребин 2009).

Учтем и тот факт, что в России начала XX века в кругах интеллигенции популярностью пользовались также лекции Рудольфа Штайнера, в которых австрийский эзотерик раскрывает образ рыцаря Парсифаля и тайну Святого Грааля [Штайнер 1998]. «В результате образ Грааля появился в творчестве

исках соперников, и даже в какой-то мере роман Фенелона (французского писателя XVIII века) о странствиях Телемака в поисках Одиссея» (Серман 1956, 552).

5 Как отмечал Н. Ладожский: «Некоторые из помещенных в сборнике рассказов представляют сложные романы, сжатые на нескольких страницах и производящие, тем не менее, довольно цельное впечатление. Таков, например, рассказ На пути, где перед читателем вырастает фигура русского Дон-Кихота, пожалуй Рудина (но гораздо более глубокого по психологии), и вспыхивает и угасает любовь к нему хорошей девушки. Обе фигуры выходят совершенно рельефно, правдиво, страстно написанными, но их роман возникает и гаснет на протяжении всего полустраницы» (Ладожский 1887).

6 Интересно отметить, что впервые о Дон Кихоте Достоевский упоминает в Романе в девяти письмах написанном в 1845 году, а позже в Объяснениях и показаниях Ф.М. Достоевского по делу петрашевцев.

7 Интересно привести в данной связи также высказывание поэта и переводчика Юрия Айхенвальда, который считал, что «Пускай Испания - историческая родина Дон Кихота. В России он нашел себе второе отечество», (Айхенвальд 2006, 305).

8 «Концерты эти становятся событиями историческими. Едва ли преувеличивал Серов, утверждая, что "прием знаменитому гостю был сделан блестящий. После каждой симфонии (Бетховена), после каждого отрывка из произведений самого Вагнера громовые аплодисменты раздавались неумолкаемо". Среди публики в зале Дворянского собрания (ныне Большой зал филармонии) и Большого театра (сегодня на его месте здание консерватории) вся петербургская музыкально-художественная элита - Балакирев, Стасов, Кюи, Одоевский, Виельгорский, Серов, братья Рубинштейны, Ларош, Чайковский и другие», (Малкиель).

9 На тему Вагнера и России см.: (Дурылин 1913; Лосев 1968; Цимборска-Лебода 1992; Bobilewicz 1996). 
А. Белого, особенно увлеченного учением Р. Штайнера, а также в поэзии не равнодушных к антропософии Черубины де Габриак, Максимилиана Волошина» - замечает Матрусова (Матрусова 2011, 4).

Очевидно, что и Елена Гуро не остается равнодушна к рыцарской тематике. Доказательством чего являются ее стихотворения и проза: Возлюбив боль поругания.., Журавлиный барон, Стихотворения в прозе, Дача с призраками, Весна, а главным образом, сверхповесть Бедный рыиарь (1913 год), в которой писательница создает образ рыцаря-духа, рыцаря-сына, выявляя его миссиию, его предназначение. Более того, Гуро несомненно были известны сочинения предшественников, о чем свидетельствуют записи в ее дневнике (Guro 1995). Поэтому можно предположить, что главный герой Бедного рыцаря - это образ собирательный, впитавший в себя аксиологические, духовные ценности своих рыцарских первоообразов (Дон Кихот Сервантеса, пушкинский паладин, князь Мышкин Достоевского, Лоэнгрин Вагнера).

В данной связи, исходной точкой для нашего анализа послужит суждение А.Н. Веселовского, выраженное в эпиграфе к настоящей статье: «... восприятие классических сюжетов иное в Roman de Troie, чем, например, у Боккаччо и французских псевдоклассиков. Уследить процессы этих усвоений, их технику, разобраться во встречных течениях, сливавшихся в разной мере для новых созданий, - представляется интересной задачей анализа» (Веселовский 1989, 304). Приняв во внимание мысль ученого, предметом наших изысканий будут способы и формы авторского (личного) осмысления Гуро культурного рыцарского мифа. Интерпретация Бедного рыщаря будет направлена на расшифровку рыцарской и инициатической символики (реминисценции ритуала посвящения), что неотъемлемо связано с аксиологической категорией рыцарства. Более того, при анализе произведения важными окажутся также ассоциативные связи и отсылки к первообразам - т.е. пушкинскому рыцарю бедному (Жил на свете рыцарь бедный...), вагнеровскому рыцарю-лебедю, Лоэнгрину, и Рыцарям Круглого Стола (символика Грааля) и др.

Отметим в первую очередь сходство бедного рыцаря Гуро с пушкинским паладином. Кроме внешнего подобия лирических героев (Цимборска-Лебода 1993; Минц 2004), их соединяет внутренняя характеристика. Так, рыцаря Пушкина характеризует смирение, благородство, верность и скромность. Именно поэтому он был достоин узреть облик Пресвятой Богоматери, служению которому посвятил свою жизнь:

Проводил он целы ночи

Перед ликом пресвятой,

Устремив к ней скорбны очи,

Тихо слезы лья рекой (Пушкин 1974, 181) 
Аналогия, вместе с тем и отличие от Пушкина, выражается в том, что в повести Гуро это Богоматерь озаряет своим взором бедного рыцаря: «И смотрела земля, как Святая Мария Дева, как Мадонна, немгного улыбаясь, на рыцаря отваги и унижения, на рыцаря нелепости, добра, на рыцаря своего верного» (Гуро 1993а, 168).

Интересно в этом контексте проследить взаимосвязь художественных текстов Пушкина Жил на свете рыцарь бедный... (1829 год), Владимира Соловьева Осення прогулка рыщаря Ральфа (1886 год) и Гуро Весна (1911 год), своеобразным интегрирующим элементом которых является мотив шарфа. В первом из произведений лирический герой - рыцарь, после того, как нашел свой идеал служения - Богоматерь, «... себе на шею четки вместо шарфа привязал» (Пушкин 1974, 181). Герой же полубаллады Вл. Соловьева, рыцарь Ральф, униженный и оскорбленный своей женой, закрывает шею большим шарфом:

Рыцарь Ральф, женой своею

Опозоренный, на шею

Навязал себе, бледнея,

Шарф большой,

И из жениной уборной,

Взяв под мышку зонтик черный,

Устремился он проворно

В лес глухой (Соловьев 1974, 143).

Мотив шарфа у Гуро появляется в ее миниатюрном рассказе Весна, написанном в 1911 году (раньше анализируемой сверхповести); ее героем является одинокий рыцарь Милосердия, внешне похожий на «дворянина из Ламанчи». Именно ему и всем одиноким рыцарям героиня рассказа готова высылать шарфы нежной шерсти и радоваться, что ее «нежный шарф ласкает ему шею» (Гуро 1993б, 63). Если учесть факт, что во всех трех случаях шарф закрывает героям шею/горло, являясь одним из инструментов выражения собственного $я$, можно предположить, что данный атрибут одежды приобретает смысл защиты. Относительно героя Пушкина, можно сказать, что он смело обнажает шею, заменив шарф на четки, так как узрел свой чистый и верный идеал служения в облике Богоматери и тем самым посвятил себя рыцарскому служению ее духовному облику. Герой же Соловьева, униженный и опозоренный дамой сердца, нуждается в защите своего израненного $я$, поэтому окрывается большим шарфом. Что же касается героини рассказа Гуро, то желая защитить от одиночества своего рыцаря, хочет послать ему связанный ею шарф, дабы он окутывал ласкою его шею. В интересующей нас сверхповести, герой сын-рыцарь, подобно пушкинскому паладину (с четками), также указан с христианскими атрибутами 
на шее, т.е. в первой части произведения с крестом: «И он протягивал ей руки и смеялся, сияя/ и сиял улыбкой/, а она спрашивала в очаровании: "Почему на тебе знаки, почему православный крест у тебя на шее, рыцарь?!"» (Гуро 1993a, 175), а во второй части с четками: «У рыцаря была исхудалая, длинная шея, и он навязывал себе жесткие четки» (Гуро 1993a, 196).

Напомним, что само определение «рыцарь», «бедный рыцарь» активно присутствует в русском философско-эстетическом дискурсе рубежа XIX-XX веков. Так, например, Блок называет Вл. Соловьева рыцарем-монахом (Блок 1962), Белый - бедным рыцарем именует П. Батюшкова [Цимборска-Лебода 1999, 188-189] и Д. Мережсковского (Цимборска-Лебода 2018, 360-383). Сам же Мережковский в своем сочинении Л. Толстой и Ф. Достоевский (1901 год) задается вопросом о смысле рыцарства, главной миссией которого, по мнению автора, является «освятить не освященное или недостаточно освященное церковью, с церковной точки зрения, все еще слишком светское, языческое; освятить не одну часть, а всю жизнь, не один полюс, а оба, не только не-я, отречение от личности, но и я, утверждение личности в сознании личного достоинства, чести, в древней героической воинствующей любви к родине, к земле, к народу, ко всему христианскому миру и в новой, вне-брачной, вне-семейной любви к женщине» (Мережковский 1995, 338-339). Рассуждение писателя, касательно задачи рыцаря, очень важно для понимания сверхповести Гуро. На наш взгляд, восприятие рыцарского долга Мережковским и автором Бедного рыцаря имеют точки соприкосновения (хотя нельзя с уверенностью утверждать, что Гуро читала книгу Мережковского). Именно с миссией посвящения прибывает рыцарь бедный в земное пространство: «Ты печально посмотри мне в глаза, я пришел к тебе радостный! Теперь дни твоего посвящения... Через меня должна ты просвятиться. О мать, мать.!» (Гуро 1993а, 173) - обращается к матери герой произведения.

Знаменателен и тот факт, что структура сверхповести Бедный рыццарь имеет характер посвящения. Она представляет собой сценарий инициации, где сама инициация понимается автором как переходный, посвятительный ритуал, в котором посвящающим является рыцарь. Сам же процесс посвящения, по мнению философа, иследователя мифологии Мирчэ Элиаде, «происходит под руководством учителя, который с помощью специального обряда одаряет ученика способностью понимания и познания. От него требуется строго хранить тайну. "Когда высшее познание возникнет в тебе, ничего не говори тем, кто не видел великий круг божественности [...], иначе связь (мистическая) порвется"» (Элиаде 1999, 272). Как духовный наставник бедный рыцарь Гуро постепенно открывает перед матерью тайну любви, той любви, которая одаряет теплом и светом все живое на земле, которая олицетворяется в красоте, в благодати, в правде, в самоотдаче. Герой повести провозглашает 
и напоминает, что земля живет любовью, Божественной любовью. И именно в смысл такой любви - христианской агапэ - посвящает Эльзу рыцарь.

Посвящение/инициация у автора Бедного рыцаря тесно связано с категорией истины. Возвращаясь к утверждению Элиаде, подчеркнем, что герой сверхповести Гуро выступает в произведении в роли посвященного учителя, что предсказывается самим названием - «бедный рыцарь», отсылающим к рыцарской символике и рыцарской традиции. Согласно культурной традиции рыцарями не становились, в рыцари посвящали ${ }^{10}$. Поэтому, посвящая свою мать в истину любви, герой Гуро говорит о себе следующее: «Тяжело слышать истину - еще тяжелей нести в мир истину. Я знаю, что моя истина не по силам тебе, но мне некому передать ее в руки, в уши, в сердце и потому я прихожу и мучаю тебя» (Гуро 1993а, 208).

О функции рыцаря как своего рода духовного проводника писал в начале XX годов русский публицист Михаил Меньшиков: «Рыцарь, поэт, монах, мудрец - в сущности, все это люди одной и той же героической породы. Они посылаются не для того, чтобы создавать вещи, а чтобы создавать в своем лице настоящих людей. Они потому нужны, что поддерживают в человечестве предания благородства и богоподобия. Пусть все тело общества заражено, нужно, чтобы оставалось хоть несколько свежих клеток. Физически обыкновенно бесплодные, рыцари, отшельники, поэты и мудрецы представляют новые побеги человеческого рода: от них именно идет свежесть и здоровье духа» (Меньшиков 2014, 240-241).

Расширяя наши рассуждения и учитывая семантику понятий «наставник», «учитель», «посвященный», «посвящающий», любопытно привести некоторые биографические факты из жизни русского художника авангардиста, Бориса Эндера, ученика Елены Гуро. Именно он, по словам Зои Эндер, являлся прототипом героя сверхповести Бедный рыщарь. Елена Гуро была для молодого поэта духовной матерью, личность и творчество которой в большой мере повлияло на его художественное миросозерцание (Эндер 1999, 261). В своих дневниковых записях Эндер называет себя учеником Гуро, ее же - пророком, пришедшим «раньше времени», мастером жизни. Обращает на себя внимание один из фрагментов дневника поэта, написанный в 1958 году. В нем Борис Эндер описывает свою очередную встречу с Гуро, во время которой он чувствовал себя посвященным писательницей: «Я отправился к Гуро, чтобы родиться поэтом. Я тогда еще не знал, что буду работать красками. Я сидел очень скромный и заплетал у скатерти косички. А она под свернувшейся калачиком собачкой на картине Бурлюка спрашивала о чем-то

10 Подробно на эту тему см. (Гюстав 2010; Норман 2008). 
не помню - понял только, что посвящаюсь. Как будто не я к ней пришел, а она явилась мне с благой вестью как архангел» (Эндер).

Анализируя сверхповесть Гуро, важно также отметить, что в процессе посвящения героиня произведения Эльза приобщается не к знанию, а к тайне -причастность к тайне указывает на нуминозный аспект феномена инициации. Знаменательно, что обряд инициации - это всегда таинство, мистерия, сопровождаемые многочисленными религиозно-мистическими атрибутами и строжайшим сохранением тайны (Ефимкина 2008, 11). Действительно, тайна и запрет характеризуют бедного рыцаря Гуро. Подобно вагнеровскому Лоэнгрину, происхождение героя повести овеяно тайной, а имя его остается загадкой. О себе рыцарь говорит следующее: «Вашего чина я не посрамлю и сияния вашего я не ношу, и никто меня не знает - за что же осудили меня? [...] Может, теперь тебе будет понятно, что я скрывать должен здесь, кто я, откуда я» (Гуро 1993a, 152).

Героя сверхповести обязывает определенный деонтологический код. Об этом свидетельствуют модальные глаголы, употребляемые Гуро для выражения запрета, например, он должен скрывать, не может показать, хотел бы рассказать, поделать этого нельзя и т.п. Бедный рыцарь осуществляет нейкий инициатический закон, к нарушению которого может привести любопытство, подозрительность и сомнение земной женщины - матери: «Ах родная, что Вы наделали! Я Вам выдал свои мечты, мою тайну. Ведь надо было беречь вещи светлые и мысли, как белых птичек, не давать их трогать грубо, любопытно и подозрительно» (Гуро 1993a, 176).

В отличие от вагнеровского Рыцаря-лебедя, бедный рыцарь Гуро подозревает возможность нарушения запрета Эльзой. Подобно Иисусу, он предвидит предательство. Со словами символического предсказания, рыцарь обращается к матери: «Но тебе еше предстоит прогнать меня, Эльза, тебе предстоит прогнать меня. На рыцаре была расстегнута сорочка и разорвана у ворота. И были видны знаки бичей и православный крест» (Гуро 1993a, 175).

Отметим еще один важный аспект рыцарства у Гуро, а именно отсылающий к символике Св. Грааля и прямым образом связанная с категорией истины и сценарием инициации. Учтем прежде всего явные отсылки в тексте: «Точно это была чаша, из которой причащались рыцари Св. Грааля» (Гуро 1993a, 192), и далее «Вы чистая чаша, светившая в ночь Рождественскую» (Гуро 1993а, 175), а также неявные, символические и ассоциативные образы. Речь идет о сказочной фигуре Периста Фениста Ясного Сокола из второй части Бедного рыцзаря, в образ которого перевоплощался рыцарь. Мистерия Грааля - это своего рода мистерия символической птицы Феникс (Сушкова $2002,86)$, являющейся символом обновления, воскресения, возрождения. Подтверждением может служить следующий фрагмент из Парсифаля Вольфрам фон Эшенбаха, характеризующий Грааля: 
Излучает волшебный свет,

Пламя, в котором, раскинув крыла,

Птица Феникс сгорает дотла,

Чтобы из пепла вспрянуть снова,

Ущерба не претерпев никакого,

А только прекраснее становясь (фон Эшенбах 1974, 113)

Ниже приведем еще один, на наш взгляд, очень важный фрагмент сверхповести Бедный рыцарь. Также и он отсылает к мистериям посвященным Граалю, которые во многом напоминали церковное таинство Причастия [Сушкова 2002, 88]: «Он входил в ее существо, чтобы она скорее вкусила мира, как бы была высшим существом и скорее узнала новые законы. И она начинала все чувствовать - как бы она была он, и не понимала, что становится с нею, - так была велика сила добра и жизни» (Гуро 1993a, 171).

Как мы видим, Гуро описывает один из моментов процесса инициации героини, в котором проявляется смысловая близость, смысловое подобие понятий «посвящение» и «причащение». Очевидно, и в мистерии инициации посвященный получает/вкушает пищу, но это пища духовная, открывающая сверхиррациональные тайны познания/постижения мира.

В заключение добавим, что для автора Бедного рыцаря Грааль является символом внутреннего человеческого опыта поисков истины. Используя рыцарскую символику, Гуро приоткрывает тайну посвящения - способность земной женщины посредством духовного просвещения пройти путь совершенствования и единения с Богом.

\section{Библиография}

Айхенвальд Юрий (2006), Из книги «Дон Кихот на русской почве», [в:] Он въезжает из другого века... Дон Кихот в России, сост. и автор вступит. статьи и примеч. Л.М. Бурмистрова, Москва, с. 302-307.

Багно Всеволод Е. (2009), Дон Кихот в России и русское донкихотство, СанктПетербург.

Белинский Виссарион Г. (1982), Собрание сочинений в 9 томах, т. 2, Москва.

Блок Александр (1962), Рыцарь-монах, [в:] Собрание сочинений в 8 томах, т. 5, Москва, с. 446-454.

Веселовский Александр Н. (1989), Историческая поэтика, Москва.

Веселовский Александр Н. (1889), Разыскания в области русского духовного стиха, Санкт-Петербург.

Гиленсон Борис А. (2016), История зарубежной литературы эпохи романтизма (первая треть XIX века), Москва. 
Гиппиус Василий В. (2014), Гоголь. Воспоминания. Письма. Дневники, Москва.

Гуро Елена (1993а), Бедный рыцарь, [в:] Ее же, Небесные верблюжата, Ростов-наДону, с. 146-214.

Гуро Елена (1993б), Весна, [в:] Ее же, Небеснье верблюжата, Ростов-на-Дону, с. 63.

Гюстав Коэн (2010), Исторя рыцарства во Франциии. Этикет, турниры, поединки, пер. В. Климанов, Москва.

Достоевский Федор М. (1989), Идиот, Ленинград.

Дурылин Сергей (1913), Вагнер и Россия. О Вагнере и будущих путях искусства, Москва.

Ефимкина Римма П. (2008), Пробуждение спящей красавиџы. Психологическая иницииция женщин в волшебных сказках, Рязань.

Жеребин Алексей (2009), Зачинатель и «завершители». Идея синтеза искусств и ее русские критики, «Вопросы литературы», № 4, с. 5-23.

Жирмунский Виктор М. (1977), Драма Александра Блока «Роза и крест», [в:] Его же, Теория литературыл. Поэтика. Стилистика, Ленинград, с. 244-321.

Ладожский Николай (1887), «Санкт-Петербургские ведомости», № 306.

Лесков Николай С. (2008), Очаровынный странник, Москва.

Лосев Алексей (1968), Проблема Рихарда Вагнера в прошлом и настоящем, «Вопросы эстетики», вып. 8, с. 67-196.

Малкиель Марина, Рихард Вагнер и его оперы на сиене Императорской русской оперы (Мариинского театра), [online:] http://wagner.su/book/export/html/187 [доступ: 25.10.2018].

Матрусова Александра Н. (2011), Легенды Артуровского иүикла в поэзии Серебряного века, автореферат диссертации на соискание ученой степени кандидата филологических наук, Москва.

Меньшиков Михаил О. (2014), Выше свободы, Москва.

Мережковский Дмитрий (1995), Вечные спутники. Сервантес, [в:] Его же, Толстой и Достоевский. Вечные спутники, Москва, с. 393-407.

Минц Зара Г. (2004), Футуризм и «неоромантизм». К проблеме генезиса и структуры «Истории бедного рыцаря» Ел. Гуро, [в:] Ее же, Блок и русский символизм. Избранные трудыл. Поэтика русского символизма, Санкт-Петербург, с. 317-326.

Норман Александр В.Б. (2008), Средневековый воин. Вооружение времен Карла Великого и Крестовых походов, пер. Л.А. Игоревский, Москва.

Пушкин Александр С. (1974), Жил на свете рыцарь бедный..., [в:] Его же, Собрание сочинений в десяти томах, т. 2, Москва, с. 180-181.

Серенков Юрий С. (2009), Артуровская легенда как ключевой текст в культурном диалоге Великобритании и США XIX-XX в., автореферат диссертации на соискание ученой степени доктора культурологии, Москва.

Серман Илья 3. (1956), Комментарий к рассказу, [в:] Н.С. Лесков, Собрание сочинений в 11 томах, т. 4, Москва, с. 551-553. 
Соловьев Владимир (1974), Осення прогулка рыцаря Ральфа, [в:] Его же, Стихотворения и шуточные пьесы, Ленинград, с. 143-144.

Сушкова Ирина В. (2002), Символизм мифологемы Грааля. Эзотерический экскурс, «Литературно-философский журнал Грааль», № 1(2), с. 75-96.

Тургенев Иван С. (1860), Гамлет и Дон Кихот, «Современник», № 1, с. 239-258.

Цимборска-Лебода Мария (1999), Герменевтика любви. Проблема эротического сознания и эротического тітеsisa в творчестве Елены Гуро, «Slavia Orientalis», № 2, с. 179-196.

Цимборска-Лебода Мария (1993), О поэтике Елены Гуро. Бедный рыцарь, «Slavia Orientalis», № 1, Warszawa, s. 43-57.

Цимборска-Лебода Мария (2018), «Рыциарь бедный» или «Странник по пустыням (не)бытия»? Андрей Бельй, Вяч. Иванов и Николай Бердяев о Мережсковском, [в:] Д.С. Мережковский: писатель - критик - мыслитель: Сборник статей, ред.-сост. О.А. Коростелев, А.А. Холиков, Москва, с. 360-383.

Чехов Антон П. (1984), На пути, [в:] Его же, Полное собрание сочинений и писем в 30-ти томах. Сочинения, т. 5, Москва, с. 462-477.

Штайнер Рудольф (1998), Христос и духовныии мир. Из поисков Святого Грааля, Шесть лекичй, прочитанных в Лейпичие с 28 декабря 1913 по 2 января 1914 года, [online:] http://www.anthroposophy.ru/index.php?go=Files\&in=view\&id=20 [доступ: 25.10.2018].

Элиаде Мирча (1999), Темы посвящения в великих религиях, [в:] Его же, Тайные общества. Обряды иницииации и посвящฺения, пер. Г.А. Гельфанд, СанктПетербург, с. 265-308.

Эндер Борис, О Елене Гуро. Из дневников художника. 1916-1959, [online:] http:// museumart.ru/art/collection/sfera/f_6g $3 \mathrm{z} 2 \mathrm{~g} /$ guro-elena/boris-ender-elena-guro.html [доступ: 20.10.2018].

Эндер Зоя (1999), Стихи 20-х годов Бориса Эндера, [в:] Школа органического искусства в русском модернизме, „Studia Slavica Finlandensia” 1999, с. 261-266.

Эшенбах фон Вольфрам (1974), Парсифаль, пер. Н. Браун, Москва.

Bobilewicz Grażyna (1996), Richard Wagner w myśli estetycznej i twórczości rosyjskich artystów przełomu XIX-XX w., [в:] W kręgu literatury rosyjskiej, red. E. Biernat, Gdańsk, c. 89-108.

Cymborska-Leboda Maria (1992), Dramat pod znakiem Dionizosa. Myśl estetyczna a poetyka gatunków symbolistów rosyjskich, Lublin.

Guro Elena (1995), Selected Writings from the Archives, Stockholm. 


\section{Summary}

\section{The Category of Knighthood and the Symbolism of the Knight in the Superstory of Elena Guro Poor knight (in Contextual Coverage)}

The material of the research in this message is the super-story of Elena Guro "Poor Knight" (1913), considered in the context of philosophical and aesthetic searches in Russia at the turn of the 19th and 20th centuries. The work is aimed at contextual analysis and hermeneutic interpretation of this work, and takes into account the specificity of perception by the author of the phenomenon of chivalry. The novelty (originality) of our research is that the interpretation of the above superstate in the context of the chivarlic tradition, the chivarlic myth of Parsifal and Lohengrin, which was undoubtedly present in the Russian cultural discourse at the turn of the 19th and 20th centuries, is offered for the first time. The proof of this will serve the works of V.S. Soloviev, M.O. Menshikov, D. Merezhskovski. In the analysis of the work, the important will be associative connections and references to the primary images-that is, Pushkin's knight (The poor knight lived in the world...), the Wagner swan knight, Lohengrin, and the knights of the round table (Grail symbolism, the symbolism of Christ's sacrifice), etc. The subject of detailed research are the ways and forms of author's (personal) comprehension of the cultural chivarlic myth by Elena Guro. The analysis of the Poor Knight will be aimed at deciphering chivarlic and initiatory symbolism (riminism of the initiation ritual), which is inherently associated with the axiological category of chivalry.

Keywords: Elena Guro; Poor Knight; the symbolism of the knight; initiation

\section{Streszczenie}

\section{Kategoria rycerstwa i symbolika rycerza w swierchpowieści Eleny Guro Biedny rycerz (w ujęciu kontekstualnym)}

Materiałem badawczym w niniejszym artykule/opracowaniu uczyniono „swierchpowieść ” Eleny Guro Бедный pыıиарь (1913), rozpatrywaną w kontekście poglądów filozoficznych i tendencji estetycznych w Rosji na przełomie XIX i XX wieku. Przedmiotem badań szczegółowych są sposoby i formy autorskiej interpretacji kulturowego mitu rycerskiego. Analiza utworu miała na celu deszyfrację symboliki rycerskiej i inicjacyjnej, która jest nieodłącznie związana z aksjologiczną kategorią rycerstwa. Artykuł przynosi pierwszą próbę interpretacji danego utworu w kontekście tradycji rycerskiej, a zwłaszcza mitu o Parsifalu i Lohengrinie, niewątpliwie obecnego w rosyjskim dyskursie kulturowym na przełomie XIX i XX wieku (W.S. Sołowjow, M.O. Mieńszikow, D. Mereżkowski). W procesie analizy dowiedziono, iż Guro, odwołując się do symboliki rycerskiej, twórczo wykorzystuje schemat inicjacji, w ramach którego bohaterka doświadcza aktu duchowego olśnienia i wtajemniczenia w istotę miłości agapicznej.

Słowa kluczowe: Elena Guro; Biedny rycerz; symbolika rycerska; inicjacja 


\section{Резюме}

Материалом исследования в настоящей статье является сверхповесть Елены Гуро Бедный рыцарь (1913 г.), рассматриваемая в контексте философско-эстетических исканий в России рубежа XIX-XX веков. Работа направлена на контекстуальный анализ и герменевтическую интерпретацию данного произведения, и учитывает специфику восприятия самим автором феномена рыцарства. Новизна предпринятого нами исследования заключается в том, что впервые предлагается интепретация вышеуказанной сверхповести в контексте рыцарской традиции, рыцарского мифа о Парсифале и Лоэнгрине, который несомненно присутствовал в русском культурном дискурсе на рубеже XIX-XX веков. Доказательством этого послужат произведения В.С. Соловьева, М.О. Меньшикова, Д. Мережсковского. При анализе произведения важными окажутся также ассоциативные связи и отсылки к первообразам - т.е. пушкинскому рыцарю (Жил на свете рыцарь бедныій...), вагнеровскому рыцарю-лебедю, Лоэнгрину, и рыцарям круглого стола (символика Грааля, символика жертвенности Христа) и др. Предметом подробных изысканий являются способы и формы авторского (личного) осмысления Еленой Гуро культурного рыцарского мифа. Анализ Бедного рыцаря будет направлен на расшифровку рыцарской и инициатической символики (реминисценции ритуала посвящения), что неотъемлемо связано с аксиологической категорией рыцарства.

Ключевые слова: Елена Гуро; Бедный рыцарь; рыцарская символика; инициация 